\title{
INOVASI DALAM ONLINE MARKETING DAN PENGARUHNYA TERHADAP KUALITAS PELAYANAN, KEPERCAYAAN, LOYALITAS, DAN WORD OF MOUTH PADA KONSUMEN
}

\author{
Handy Januar Permana ${ }^{1}$ \\ Wahyu Hidayat ${ }^{2}$ \\ Arif Marjuki ${ }^{3}$ \\ Dosen STMIK Raharja ${ }^{1,2}$, AMIK Raharja Informatika ${ }^{3}$ \\ Jl. Jendral Sudirman No. 40, Modern Cikokol, Tangerang ${ }^{1,2,3}$ \\ Email: handy.permana@raharja.info ${ }^{1)}$,wahyu@raharja.info ${ }^{2)}$, arif.marjuki@raharja.info $^{3)}$
}

\begin{abstract}
ABSTRAK
Latar belakang makalah ini membahas peran persepsi konsumen inovasi website sebagai faktor yang mempengaruhi evaluasi mereka kualitas pelayanan, pengembangan kepercayaan, loyalitas dan firman perilaku mulut di situs. Penelitian ini bertujuan untuk menjawab pertanyaan sepanjang tidak mengalami evaluasi inovasi situs layanan dari pengaruh kualitas website, kepercayaan, loyalitas dan dari mulut ke mulut. Oleh karena itu, untuk menjawab pertanyaan ini penelitian ini dikembangkan dan diuji model teoritis yang berusaha untuk menjelaskan efek yang dirasakan inovasi situs-layanan pada kualitas yang dirasakan e-service, kepercayaan, situs loyalitas dan kata-of-mulut perilaku dalam ruang pasar e-retail. Desain penelitian didasarkan pada tanggapan yang valid dikumpulkan dari survei kuesioner dari 120 orang yang berlokasi di Jakarta. Variabel yang diteliti dalam penelitian ini menggunakan Kuadrat Terkecil Parsial (PLS), khususnya PLS-IMAGE v.3.00 untuk menilai relevansi dari prediksi model konseptual, dan menguji hubungan hipotesis seperti yang digambarkan dalam gambar. Hasil penelitian menunjukkan bahwa ketika sebuah situs e-retail dianggap positif untuk menyediakan pengalaman yang inovatif evaluasi lebih positif mempengaruhi persepsi keseluruhan kualitas layanan online, tingkat kepercayaan yang tinggi dan loyalitas website dan sisi positif dari mulut perilaku percakapan. Studi ini memberikan implikasi penting untuk pengiriman layanan online dan secara online branding, terutama untuk pengecer online. Penelitian tambahan diperlukan untuk melihat dampak dari suatu inovasi dalam pemasaran online dengan menambahkan variabel lain yang dianggap penting terkait dengan inovasi.
\end{abstract}

Kata kunci: Inovasi, kualitas layanan, kepercayaan, loyalitas dan dari mulut ke mulut.

\begin{abstract}
The background of this paper discusses the role of consumer perceptions of innovation a website as a factor influencing their evaluation of service quality, development of trust, loyalty and word of mouth behavior on the site. This study aims to answer the question the extent not experienced site service innovation evaluation of the influence of website quality, trust, loyalty and word of mouth. Therefore, to answer this question this study developed and tested a theoretical model that seeks to explain the perceived effects of site-service innovation on perceived e-service quality, trust, loyalty sites and word-of-mouth behavior in e-retail market space. The study design is based on valid responses were collected from a questionnaire survey of 120 people located in Jakarta. The variables examined in this study using the Partial Least Squares (PLS), specifically PLS-IMAGE v.3.00 to assess the relevance of the predictions of the conceptual model, and test the hypothesis relationship as depicted in picture. Results showed that when an e-retail sites considered positive for providing an innovative experience more positive evaluations affect the overall perception of the quality of online services, high level of trust and loyalty websites and the positive side of the conversation behavior mouth. This study provides important implications for the delivery of online services and online branding, especially for online retailers. Additional research is needed to see the impact of an innovation in online marketing by adding other variables that are considered important are associated with innovation.
\end{abstract}

Keywords: Innovation, service quality, trust, loyalty and word of mouth. 


\section{PENDAHULUAN}

Belanja merupakan salah satu hal yang menyenangkan memberi hiburan juga perasaan senang untuk membeli sesuatu. Ini bersifat universal dalam kehidupan setiap orang dalam menghabiskan banyak waktu dalam berbelanja. Selama bertahun-tahun standar hidup telah berubah untuk sebagian besar orang dan juga ternyata menjadi gaya tersendiri dengan kehidupan yang sangat sibuk. Dengan hidup di era gaya bahkan dalam kehidupan yang sibuk dan super sibuk. Kadang-kadang, menjadi sangat sulit bagi kebanyakan orang untuk pergi ke pasar untuk berbelanja. Menjaga dalam melihat pertumbuhan permintaan dari belanja online, pengusaha telah membuat portal belanja online yang sangat inspiratif dan menguntungkan bagi pelanggan. Belanja online dengan cepat menjadi pilihan pertama orang di dunia untuk belanja modern atau tradisional. Secara bertahap, belanja online sedang diterima sebagai cara baru dan modis belanja. Hal ini menjadi populer karena orang memiliki hal-hal lain yang harus dilakukan dalam kehidupan yang sibuk dengan belanja online dapat menghemat waktu dengan berbagai cara. Proses belanja online telah menjadi sangat sederhana dan mudah. Belanja online adalah sebuah pasar online di mana jumlah toko dari merek yang berbeda memberikan layanan mereka di bawah situs yang sama dalam waktu 24 jam yang tersedia setiap hari dan setiap saat sepanjang tahun.

Kemajuan dalam teknologi informasi dan komunikasi (misalnya aplikas Web 2.0 dan platform) yang disampaikan melalui antarmuka situs web yang telah memungkinkan penciptaan pengalaman merk layanan baru yang memungkinkan interaksi yang lebih besar, control dan individualisasi dalam lingkungan belanja e-retail (Cho and Menor, 2010; Davis et al., 2000; Hausman and Siekpe, 2009). Dari perspektif merek layanan, makna merek yang diperoleh pelanggan yang timbul dari pengalaman konsumsi ritel disampaikan oleh pengecer online dapat membentuk citra merek yang kuat (Davis et al., 2000).

\section{PERMASALAHAN}

Sesuai dengan latar belakang di atas maka perumusan masalah yang diperoleh sebagai berikut:

1. Adakah pengaruh positif inovasi terhadap service quality?

2. Adakah pengaruh positif inovasi terhadap kepercayaan?

3. Adakah pengaruh positif inovasi terhadap loyalitas?

4. Adakah pengaruh positif inovasi terhadap word of mouth?

\section{LANDASAN TEORI}

Pemasaran marketing merupakan sebuah konsep ilmu dalam strategi bisnis yang bertujuan untuk mencapai kepuasaan berkelanjutan bagi stakeholder (pelanggan, karyawan, pemegang saham). Menurut Philip Kotler/Armstrong (2002:14), yang diterjemahkan Wilhelmus W. Bakowatun menyebutkan bahwa : Manajemen pemasaran adalah analisis, perencanaan, pelaksanaan, dan pengendalian atas program yang dirancang untuk menciptakan, membangun, dan mempertahankan pertukaran yang menguntungkan dengan pembeli sasaran dengan maksud untuk mencapai sasaran organisasi". Menurut Philip William J. Shultz (dalam buku Prof. Dr. H. Buchari Alma, "Manajemen Pemasaran dan Pemasaran Jasa", cetakan-7, 2005, hal 130), Manajemen pemasaran adalah merencanakan, pengarahan, dan pengawasan seluruh kegiatan pemasaran perusahaan ataupun bagian dari perusahaan Sebagai ilmu, marketing merupakan ilmu pengetahuan yang obyektif, yang diperoleh dengan penggunaan instrumen-instrumen tertentu untuk mengukur kinerja dari aktivitas bisnis dalam 
membentuk, mengembangkan, mengarahkan pertukaran saling menguntungkan dalam jangka panjang antara produsen dan konsumen atau pemakai. Sebagai strategi bisnis, marketing merupakan tindakan penyesuaian suatu organisasi yang berorientasi pasar dalam menghadapi kenyataan bisnis,baik dalam lingkungan mikro maupun lingkungan makro yang terus berubah. Dalam lingkungan bisnis yang berubah cepat, setiap bisnis harus menang di market yang berubah, marketing harus dilihat sebagai "dealing with the market" yang mengharuskan marketer untuk dinamis dan intensif berinteraksi dengan market. Pasar sekarang berubah sangat cepat, pelanggan sangat sensitif terhadap harga, kompetitor baru bermunculan, saluran distribusi baru dan saluran komunikasi baru juga semakin canggih-interrnet, teleconference dan teknologi yang mendukung pasar menjadi pendukung bangkitnya otomasi penjualan dan pemasaran.

\section{Inovasi}

Faktor terbaik dalam kemajuan bisnis adalah pemasaran dan inovasi. Pemasaran dan inovasi memberikan hasil dan sangat berperan terhadap keberlangsungan suatu perusahaan dalam masa depan, selebihnya merupakan biaya-biaya. Inovasi bukan sekedar berkutat dengan penciptaan produk yang baru dan lebih baik, tetapi juga pengembangan sistem yang lebih baik dan konsep bisnis yang baru. Inovasi adalah semacam perubahan namun perubahan tidak bisa disebut inovasi. Inovasi adalah transformasi pengetahuan kepada produk, proses dan jasa baru; tindakan menggunakan sesuatu yang baru (Rosenfeld, 2002). Inovasi merupakan eksploitasi yang berhasil dari suatu gagasan baru (the successful exploitation of a new idea; Mitra, 2001 dan the British Council, 2000), atau dengan kata lain merupakan mobilisasi pengetahuan, keterampilan teknologis dan pengalaman untuk menciptakan produk, proses dan jasa baru. Perusahaan yang selalu berinovasi dan berkreasi dengan hal-hal yang baru yang difundalisasi oleh system research dan development yang sangat super itulah yang sanggup bertahan dalam kondisi apapun dan jaminan keberlangsungan dimasa depan. Kaitan dengan inovasi, suatu perusahaan dapat menjadi lebih kreatif dan berinovatif dengan melakukan hal berikut :

1. Merekrut dan memberdayakan orang-orang yang kreatif dan berdaya inovasi yang selalu berbeda, yang pikirannya terus berputar, selalu ingin tahu, dan selalu bertanya.

2. Menggunakan tool dalam proses kreativitas guna memecahkan masalah perusahaan.

3. Menggunakan jasa agen kreatif yang dapat membantu dalam memunculkan ide-ide baru bagi perusahaan.

\section{Kualitas Pelayanan}

Kualitas merupakan inti kelangsungan hidup sebuah lembaga. Gerakan revolusi mutu melalui pendekatan manajemen mutu terpadu menjadi tuntutan yang tidak boleh diabaikan jika suatu lembaga ingin hidup dan berkembang, Persaingan yang semakin ketat akhir-akhir ini menuntut sebuah lembaga penyedia jasa/layanan untuk selalu memanjakan konsumen/pelanggan dengan memberikan pelayanan terbaik. Para pelanggan akan mencari produk berupa barang atau jasa dari perusahaan yang dapat memberikan pelayanan yang terbaik kepadanya (Assauri, 2003). Kualitas pelayanan merupakan komponen penting dalam persepsi konsumen, juga sangat penting dalam pengaruhnya terhadap kepuasan konsumen. Semakin baik kualitas maka jasa yang diberikan maka akan semakin baik pula citra jasa tersebut dimata konsumen.Menurut Zeithaml et al. (2006) ciri-ciri dari kulitas jasa adalah sebagai berikut : 
1. Kualitas jasa sangat sulit untuk dilakukan evaluasi dibandingkan dengan kualitas barang.

2. Kualitas jasa merupakan perbandingan hasil dari pandangan konsumen antara harapan dan kenyataan.

Kriteria untuk menentukan kualitas jasa akhirnya dikembalikan kepada konsumen sendiri. Pandangan pada suatu kualitas jasa dimulai bagaimana penyedia jasa dapat memenuhi harapan konsumen. Pada penelitian selanjutnya yang dilakukan Parasuraman et al. (2008) dalam Kotler dan Keller (2013) dan dalam Lovelock dan Wright (2007), dari sepuluh dimensi service quality yang dihasilkan dari penelitian sebelumnya ditemukan intisari dari kualitas layanan yang dilebur menjadi lima dimensi dari service quality yang dikenal sebagai SERVQUAL yaitu :

1. Reliability (keandalan), kemampuan melaksanakan layanan yang dijanjikan secara meyakinkan dan akurat.

2. Responsiveness (ketanggapan), kesediaan membantu konsumen dan memberikan jasa dengan cepat.

3. Assurance (jaminan), pengetahuan dan kesopanan serta kemampuan mereka menyampaikan kepercayaan dan keyakinan.

4. Empathy (empati), kesediaan memberikan perhatian yang mendalam dan khusus kepada masing-masing konsumen.

5. Tangibles (benda berwujud), penampilan fisik, perlengkapan, karyawan dan bahan komunikasi. Memberikan kualitas pelayanan dipertimbangkan sebagai sebuah strategi penting supaya sukses dan bertahan dalam lingkungan persaingan saat ini. Kualitas pelayanan adalah tingkatan dimana dapat memenuhi atau melebihi harapan konsumen. Dapat ditarik kesimpulan bahwa kualitas jasa adalah suatu tingkat sejauh mana kemampuan pelayanan perusahaan dapat memenuhi harapan konsumen. Semakin besar kesenjangan antara harapan dan kemampuan pelayanan menyebabkan tingkat ketidak puasan konsumen semakin besar pula.

\section{Kepercayaan}

Kepercayaan merupakan pondasi dari bisnis, suatu transaksi bisnis antara dua pihak atau lebih akan terjadi apabila masing-masing saling mempercayai. Kepercayaan ini tidak begitu saja dapat diakui oleh pihak lain/mitra bisnis, melainkan harus dibangun mulai dari awal dan dapat dibuktikan (Rofiq 2007). Keyakinan adalah suatu sikap yang ditunjukan oleh manusia saat ia merasa cukup tabu dan menyimpulkan bahwa dirinya telah mencapai kebenaran. Karena keyakinan merupakan suatu sikap, maka keyakinan seseorang tidak selalu benar atau keyakinan semata bukanlah jaminan kebenaran (id.wikipedia.org). pengertian lain dari kepercayaan konsumen berbelanja online adalah "Keinginan konsumen akan tindakan yang peka dari vendor internet saat transaksi online, didasari harapan bahwa vendor internet akan berprilaku jujur, terlepas dari kemampuan konsumen untuk memantau atau mengontrol vendor internet (Lee dan Turban 2001) dalam Cheung dan Lee (2008).

Hubungan tingkat kepercayaan konsumen terhadap resiko adalah apabila konsumen sudah percaya pada belanja online maka konsumen sudah mengetahui risiko apa yang akan ada, jika konsumen melakukan transaksi online beberapa kali dan transaski tersebut sesuai barang yang diterima sesuai harapan, keamanan data saat transaksi, pengiriman barang, dan saat pembayaran maka risiko akan berkurang. 


\section{Loyalitas Situs}

Kinerja dari sebuah situs web, jika dilihat melalui atribut dianggap sebagai positif, merupakan faktor penentu yang penting niat perilaku. Sebagai contoh, penelitian sebelumnya telah menunjukkan bahwa website atribut termasuk konten informasi, hiburan, kegunaan, kemampuan transaksi, dan estetika desain mempengaruhi niat konsumen untuk berbelanja di website dan meninjau kembali situs di masa depan (misalnya Bauer et al, 2006;. Hausman dan Siekpe, 2009; Loiacono, Watson dan Goodhue, 2007). Studi juga menunjukkan bahwa konsumen yang memiliki sikap yang lebih baik terhadap situs web lebih mungkin untuk berbelanja di situs (Ha dan Stoel, 2009; Kim dan Lee, 2006), dan bahwa pelanggan yang menunjukkan tingkat yang lebih tinggi dari kenikmatan memiliki lebih positif persepsi lingkungan toko online (Childers et al., 2001)

\section{Kerangka Pemikiran}

Semakin pentingnya dan dampak dari teknologi memungkinkan pengalaman pelayanan dalam perekonomian saat ini telah menciptakan bunga yang signifikan dalam industri, pemerintah dan akademisi di seluruh dunia.Kontribusi utama dari studi ini adalah bahwa ia menyediakan e-retail peneliti dan praktisi dengan wawasan tambahan untuk mempertimbangkan konstruk penting dirasakan situs-layanan inovasi dan dampaknya saat penempaan tayangan pelanggan dan hubungan dalam konteks e-ritel. Isu-isu ini penting dan strategis mengingat fitur yang mendasari bisnis layanan yang paling sukses adalah fokus tak henti pada pelanggan di mana semua strategi seluruh inovasi, kualitas dan peningkatan pelayanan mempertimbangkan perspektif pelanggan (Ostrom et al, 2010;. Zeithaml et al. , 2006).

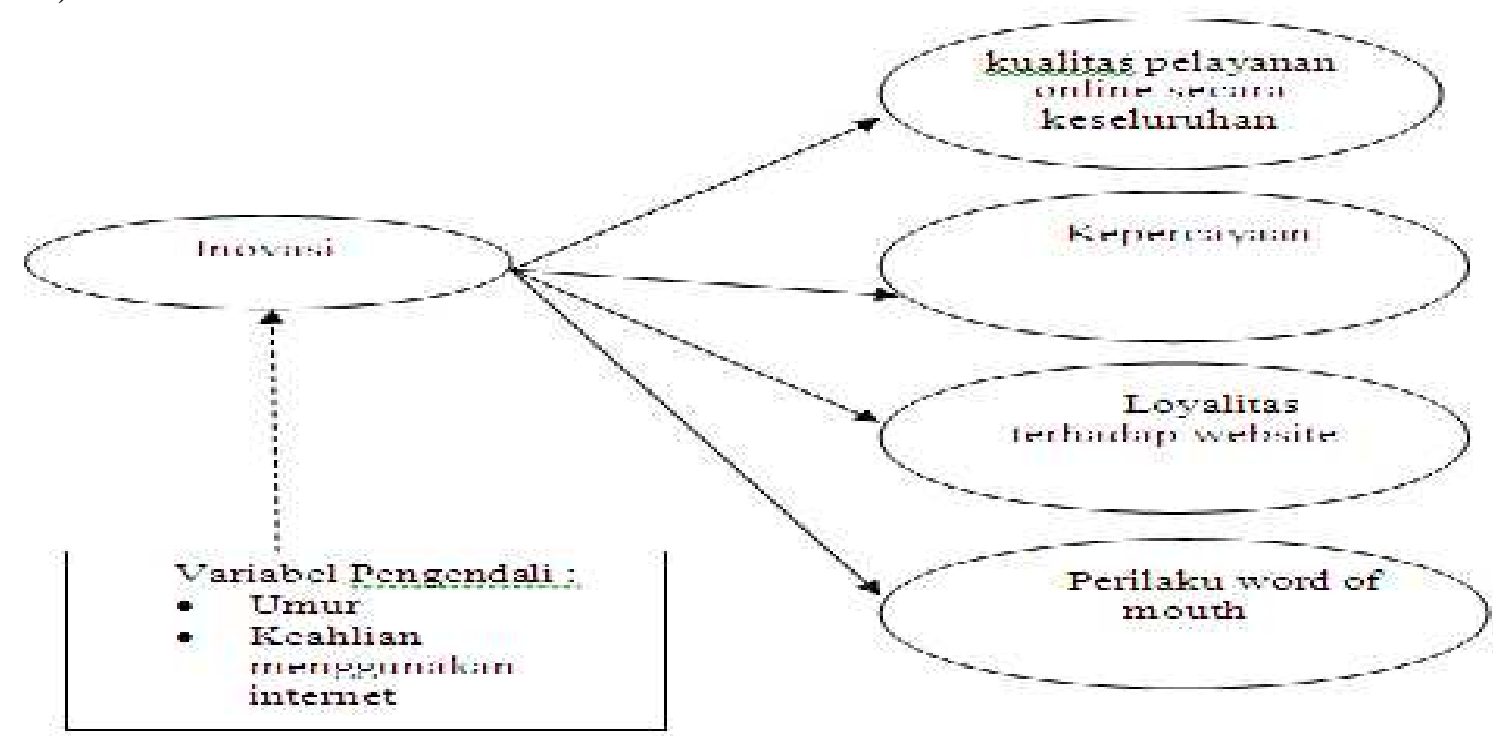

Gambar 2.1 Kerangka Konseptual

\section{Perumusan Hipotesis}

Dalam konteks penelitian ini, peneliti berpendapat bahwa setelah seorang pelanggan membuat penilaian bahwa website-layanan pengalaman pengecer dianggap untuk menjadi 
inovatif, konsumen akan lebih cenderung untuk mengevaluasi website telah memberikan kualitas layanan e-. Dengan demikian, dapat dibuat hipotesis sebagai berikut :

H1. Situs-layanan inovasi secara positif berpengaruh terhadap e-service quality.

Peneliti berpendapat bahwa konsumen ritel yang mengevaluasi pengalaman website pengecer untuk menjadi inovatif maka akan lebih mungkin untuk membentuk secara online yang menguntungkan percaya persepsi dari situs pengecer. Berdasarkan pendapat tersebut, dapat dirumuskan hipotesis sebagai berikut :

\section{H2. Situs-layanan inovasi secara positif berpengaruh terhadap kepercayaan secara online.}

Dengan demikian, peneliti berpendapat bahwa persepsi yang menguntungkan dari situslayanan inovasi yang timbul dari proses interaksi antara konsumen dan website pengaruh pengecer revisitation website, mengurangi kemungkinan perilaku beralih dan niat untuk membeli. Dengan demikian, dapat ditetapkan hipotesis sebagai berikut:

\section{H3. Situs-layanan inovasi secara positif berpengaruh terhadap loyalitas situs.}

Dalam situasi seperti itu, informasi dari keuntungan pelanggan lain peran pentingnya dalam evaluasi pelayanan sejak layanan konsumen sangat bergantung pada pendapat konsumen lain ketika membentuk sebuah harapan tentang layanan, serta ketika mengevaluasi pelayanan diperoleh (Haywood, 2009). Dengan demikian, dapat ditetapkan hipotesis sebagai berikut :

\section{H4. Situs-layanan inovasi secara positif berpengaruh terhadap word of-mouth}

\section{METODOLOGI}

Variabel yang menarik dalam penelitian ini diukur dengan menggunakan skala mapan dari sistem informasi, pemasaran dan sastra perilaku pelanggan dan disesuaikan dengan konteks penelitian ini. Pengukuran dirasakan situs-layanan inovasi didasarkan pada karya Loiacono dkk. (2007). Secara keseluruhan kualitas layanan online diukur dengan metode Dabholkar et al. (2000) yang termasuk tiga item. Pengukuran secara online kepercayaan didasarkan pada Bart et al. (2005) dan Loiacono et al. (2007). Situs loyalitas dan WOM diukur sebagai konstruksi terpisah dengan dua item masing-masing dan diambil dari Zeithaml et al 's. (2001), yang telah menjadi ukuran umum untuk menilai niat perilaku loyalitas konsumen dalam konteks pemasaran jasa. Kami membagi ukuran asli menjadi dua komponen yang terpisah untuk membentuk dua konstruksi yang terpisah untuk menilai niat perilaku. Loyalitas, website pertama termasuk barang-barang seperti niat perilaku beralih, niat pembelian dan revisitation situs, dan membangun kedua, Word-of-mulut perilaku rekomendasi (lihat Tabel 1 untuk item). Semua item diukur pada tujuh poin Likert-jenis skala (sangat tidak setuju (1) sampai sangat setuju (7)).

\section{Inovasi Layanan Website}

Sebagai contoh, penelitian sebelumnya telah menunjukkan bahwa website atribut termasuk konten informasi, hiburan, kegunaan, kemampuan transaksi, dan estetika desain mempengaruhi niat konsumen untuk berbelanja di website dan meninjau kembali situs di masa depan (misalnya Bauer et al, 2006;. Hausman dan Siekpe, 2009; Loiacono, Watson dan Goodhue, 2007).

1. Website pengecer menawarkan fitur unik untuk pelanggan yang berbeda dari situs-situs ritel yang ada. 
2. Situs ritel sangat inovatif.

3. Website pengecer memiliki fitur inovatif.

\section{Keseluruhan Kualitas E-Service}

Studi merek sebelumnya secara online telah menunjukkan bahwa berdasarkan persepsi mereka tentang merek, konsumen menanggapi produk atau layanan dengan tanggapan tersebut menemukan itu berguna /tidak berguna, mengidentifikasi mereka suka/tidak suka, atau mereka mungkin mendekati/menghindari membeli itu (Bloch, 2005; mono, 2007).

1. Secara keseluruhan, kualitas situs pengecer buruk/sangat baik.

2. Secara keseluruhan, kualitas situs pengecer tidak berharga/berharga

3. Secara keseluruhan, kualitas situs pengecer rendah standar/standar tinggi.

\section{Kepercayaan}

Kepercayaan melibatkan kesediaan seseorang untuk bertingkah laku tertentu karena keyakinan bahwa mitranya akan memberikan apa yang ia harapkan dan suatu harapan yang umumnya dimiliki seseorang bahwa kata, janji atau pernyataan orang lain dapat dipercaya (Barnes dalam Rini, 2007). Ini menjadi kasus, konsumen ritel mengembangkan persepsi kepercayaan berdasarkan pengalaman situs web mereka, seperti kemampuan untuk website untuk memberikan konten inovatif dan relevan, fitur keamanan, fasilitasi efisien pembelian dan sejenisnya (Bart et al, 2005;. Chen dan Dibbs, 2010).

\section{Loyalitas Website}

Pemberian layanan yang lain juga menyangkut dalam hal melakukan sesuatu yang paling kecil yang diharapkan oleh pelanggan (Devrye, 2003). Pemberian layanan yang baik pada pelanggan akan menciptakan konsumen yang loyal, yaitu konsumen yang senang karena mereka memilih perusahaan setelah merasakan pengalaman layanan, pelanggan akan menggunakan jasa layanan perusahaan kembali, dan mempromosikan perusahaan tersebut pada orang lain. Kaitan antara loyalitas pelanggan dan kualitas layanan juga dikemukakan oleh Zeithaml,et al. Dalam penelitiannya, dikemukakan bahwa kualitas layanan berpengaruh secara signifikan terhadap perilaku konsumen untuk loyal terhadap suatu layanan/produk (Zeithaml.el.al dalam Agung ,2006). Pelanggan yang loyal akan memberikan pemasukan bagi kas perusahaan (Kartajaya,2009).

\section{Word Of Mouth}

Dalam pengaturan jasa, WOM diyakini memainkan peran yang lebih penting daripada barang karena karakteristik spesifik dari layanan seperti intangibility dan non-standardisasi, integrasi pelanggan dalam proses pelayanan, yang semuanya menambah persepsi risiko yang lebih tinggi dari konsumen sebelum menggunakan layanan ini (Zeithaml et al., 2006).

\section{Persepsi Internet Keahlian}

Kami mengontrol keahlian internet dianggap untuk memperhitungkan fakta bahwa pengalaman penggunaan telah terbukti memiliki peran utama dalam lingkungan Internet dalam kaitannya dengan perilaku belanja (Bridges dan Florsheim, 2008; O'Cass dan Fenech, 2003).

1. Saya dengan mudah bisa menggunakan world wide web untuk informasi tentang suatu produk/ jasa. 
2. Saya biasa mendapatkan ke situs web tertentu menggunakan browser.

3. Saya memiliki keterampilan dan pengalaman untuk mencari world wide web sendiri.

4. Saya akan dapat menggunakan internet pada diri saya sendiri untuk menemukan situs web sendiri.

5. Saya merasa bahwa saya adalah pengguna yang berpengalaman dari internet.

\section{Populasi dan Sampel}

Penelitian ini didasarkan pada evaluasi konsumen Jakarta terhadap situs pengecer sebanyak 120 orang. Dalam rangka untuk mengumpulkan data yang diperlukan untuk menguji kerangka teoretis (H1 ke H4), kuesioner self-administered online adalah melakukan melalui perusahaan riset pasar Jakarta. Perusahaan yang dipilih secara acak individu dari panel online. Individu-individu terpilih menerima e-mail yang berisi link survei online atau dan diminta untuk mengingat sebuah pertemuan baru-baru ini dengan situs ritel di mana setidaknya satu pembelian telah dibuat dalam enam bulan terakhir dan merujuk ke situs web tentang jawaban mereka. Kriteria yang di gunakan dalam penelitian ini adalah jenis kelamin, usia, pekerjaan, pendapatan.

\section{Uji Validitas dan Reliabilitas Data}

Langkah pertama dalam menganalisis data penelitian adalah dengan uji validitas dan reliabilitas yang bertujuan untuk pembuktian yang dapat menunjukan bahwa semua indicator layak digunakan sebagai indicator konstruk. Koefisien alpha (cronbach alpha) memili nilai yang sangat tinggi yakni 0.915 hal tersebut berarti reliabilitas kuesioner tergolong sangat baik.

\section{Uji Validitas}

Penelitian ini menggunakan data kuesioner sebagai data primer, sehingga diperlukan langkah uji coba pertanyaan (kuesioner) untuk mengetahui apakah pertanyaan tersebut layak atau tidak uji untuk mengetahui layak dan tidaknya pertanyaan digunakan uji validitas. Uji ini digunakan untuk mengukur kelayakan dan kevalidan suatu system pertanyaan. Kriteria keputusan, apabila nilai corrected item-total correction lebih besar dari $\mathrm{r}$ table maka indicator layak dan sebaliknya (Imam Ghozali, 2005). Uji validitas pada penelitian ini menggunakan Total - Item Statistic yang dapat dilihat dalam tabel berikut:

Tabel. Item-Total Statistics

\begin{tabular}{|l|c|c|c|c|c|}
\hline & $\begin{array}{c}\text { Scale Mean if } \\
\text { Item Deleted }\end{array}$ & $\begin{array}{c}\text { Scale Variance if } \\
\text { Item Deleted }\end{array}$ & $\begin{array}{c}\text { Corrected } \\
\text { Item-Total } \\
\text { Correlation }\end{array}$ & $\begin{array}{c}\text { Squared } \\
\text { Multiple } \\
\text { Correlation }\end{array}$ & $\begin{array}{c}\text { Cronbach's } \\
\text { Alpha if Item } \\
\text { Deleted }\end{array}$ \\
\hline ILW01 & 47.8667 & 49.360 & .617 & .453 & .909 \\
ILW02 & 47.8917 & 48.299 & .643 & .489 & .908 \\
ILW03 & 47.9333 & 47.928 & .687 & .503 & .907 \\
KKES01 & 47.9500 & 48.737 & .579 & .437 & .910 \\
KKES02 & 47.9750 & 48.058 & .655 & .479 & .908 \\
KKES03 & 48.0333 & 47.545 & .641 & .486 & .908 \\
K01 & 47.8500 & 48.145 & .685 & .530 & .907 \\
K02 & 47.8750 & 48.951 & .596 & .436 & .910
\end{tabular}




\begin{tabular}{|l|l|l|l|l|l|} 
|K03 & 47.8167 & 48.101 & .628 & .539 & .909 \\
K04 & 47.9333 & 48.718 & .602 & .451 & .909 \\
LW01 & 47.9833 & 46.924 & .739 & .625 & .905 \\
LW02 & 48.0000 & 45.496 & .690 & .570 & .907 \\
LW03 & 48.0500 & 47.241 & .749 & .689 & .905 \\
PWOM01 & 47.9667 & 50.133 & .550 & .501 & .911 \\
PWOM02 & 47.7750 & 51.218 & .269 & .316 & .922 \\
\hline
\end{tabular}

Dari tabel tersebut dapat diketahui bahwa semua variabel memiliki nilai Corrected Item-Total Correlation diatas 0.1 (tabel $\mathrm{r}$ product moment sampel 120) sehingga dinyatakan bahwa seluruh pertanyaan dinyatakan valid.

\section{Uji Reliabilitas}

Uji reliabilitas dalam penelitian ini menggunakan pengujian Cronbach Alpha dengan hasil berikut:

Tabel. Reliability Statistics

\begin{tabular}{|c|c|c|}
\hline $\begin{array}{c}\text { Cronbach's } \\
\text { Alpha }\end{array}$ & $\begin{array}{c}\text { Cronbach's } \\
\text { Alpha Based } \\
\text { on } \\
\text { Standardized } \\
\text { Items }\end{array}$ & N of Items \\
\hline .915 & .917 & 15 \\
\hline
\end{tabular}

Dari hasil tersebut terlihat bahwa nilai Cronbach Alpha yang sangat tinggi yakni 0.915. Hal tersebut berarti reliabilitas kuesioner tergolong sangat baik.

\section{LITERATURE REVIEW}

1. PENGARUH INOVASI PRODUK, HARGA, CITRA MEREK DAN KUALITAS PELAYANAN TERHADAP LOYALITAS PELANGGAN SEPEDA MOTOR VESPA, oleh Made Caesar Surya Dwi Putra dan Ni Wayan. Penelitian ini bertujuan untuk menjelaskan pengaruh inovasi produk, harga, citra merek, dan kualitas pelayanan terhadap loyalitas pelanggan di kota Denpasar. Sampel yang digunakan sebanyak 102 responden dengan metode purposive sampling. Pengumpulan data pada penelitian ini menggunakan kuesioner dan wawancara. Teknik analisis yang digunakan dalam penelitian ini adalah analisis regresi linier berganda. Berdasarkan hasil analisis ditemukan bahwa inovasi produk memiliki pengaruh positif dan signifikan terhadap loyalitas pelanggan sepeda motor vespa di kota Denpasar. Harga memiliki pengaruh positif dan signifikan terhadap loyalitas pelanggan sepeda motor vespa di kota Denpasar. Citra merek memiliki pengaruh positif dan signifikan terhadap loyalitas pelanggan sepeda motor vespa di kota Denpasar. Kualitas pelayanan memiliki pengaruh positif dan signifikan terhadap loyalitas pelanggan sepeda motor vespa di kota Denpasar. Hal membuktikan bahwa inovasi produk, harga, citra merek, dan kualitas pelayanan dapat meningkatkan loyalitas pelanggan sepeda motor Vespa di kota Denpasar.

2. PENGARUH WORD OF MOUTH MARKETING TERHADAP KEPUTUSAN PEMBELIAN KONSUMEN (SURVEI PADA KONSUMEN RESTO D'COST 
SEAFOOD SUKAJADI NO. 197, BANDUNG) oleh Dedy Afriansyah ${ }^{1}$, Rah Utami Nugrahani ${ }^{2}$. WoM Marketing dianggap cukup efektif dalam mempengaruhi konsumen untuk melakukan pembelian dibandingkan media komunikasi lainnya. Riset Nielsen (di Amerika Serikat) pada perusahaan yang menggunakan WoMM menyimpulkan kepercayaan konsumen dalam melakukan pembelian terbentuk dari rekomendasi orang lain (keluarga, teman, kerabat, dll). Sehingga penelitian ini ingin mengetahui pengaruh WoMM terhadap keputusan pembelian konsumen (Survei pada konsumen D'Cost seafood sukajadi Bandung). Penelitian ini menggunakan pendekatan kuantitatif. Sampel diambil sebanyak 120 responden dengan teknik accidental sampling. Hasil penelitian menunjukkan WoMM berpengaruh positif dan signifikan terhadap keputusan pembelian konsumen. Diamana WoMM mempengaruhi keputusan pembelian konsumen sebesar 45\%. Dan sisanya 55\% dipengaruhi oleh faktor lain yang tidak dijelaskan dalam penelitian ini. Implikasi manajerial, disarankan agar D'Cost dapat terus memperhatikan perihal yang mempengaruhi terjadinya penyebaran WoMM. D'Cost juga harus mampu menciptakan diferensiasi keunikan produk, kualitas dan memposisikan produk yang pantas dibeli, serta perlunya memberikan pelayanan maksimal kepada konsumen sehingga membuat konsumen bahagia. Ini penting untuk memicu WoMM positif, karena dalam penyebaran WoMM konsumen yang memainkan peran dalam menentukan hal untuk dibicarakan.

\section{PEMBAHASAN}

Statistik adalah ilmu yang mempelajari bagaimana merencanakan mengumpulkan menganalisis menginterpretasi dan mempresentasikan data. Statistika merupakan ilmu yg berkenaan dgn data sedang statistik adl data informasi atau hasil penerapan algoritma statistika pada suatu data. Beberapa istilah statistika antara lain: populasi sampel unit sampel dan probabilitas. Ada dua macam statistika yaitu statistika deskriptif dan statistika inferensial. Statistika deskriptif berkenaan dengan deskripsi data misal dari menghitung ratarata dan varians dari data mentah; mendeksripsikan menggunakan tabel-tabel atau grafik sehingga data mentah lebih mudah "dibaca" dan lebih bermakna. Sedangkan statistika inferensial lebih dari itu misal melakukan pengujian hipotesis melakukan prediksi observasi masa depan atau membuat model regresi.

\section{Analisis statistik deskriptif}

Berkenaan dengan bagaimana data dapat digambarkan dideskripsikan) atau disimpulkan baik secara numerik (misal menghitung rata-rata dan deviasi standar) atau secara grafis (dalam bentuk tabel atau grafik) utk mendapatkan gambaran sekilas mengenai data tersebut sehingga lbh mudah dibaca dan bermakna. Statistik deskriptif atau statistik deduktif adalah bagian dari statistik mempelajari cara pengumpulan data dan penyajian data sehingga mudah dipahami. Statistik deskriptif hanya berhubungan dengan hal menguraikan atau memberikan keterangan-keterangan mengenai suatu data atau keadaan atau fenomena. Dengan kata lain, statistik deskriptif berfungsi menerangkan keadaan, gejala, atau persoalan. Penarikan kesimpulan pada statistik deskriptif (jika ada) hanya ditujukan pada kumpulan data yang ada. Yang dimaksud sebagai statistika deskriptif adalah bagian statistika mengenai pengumpulan data, penyajian, penentuan nilai-nilai statistika, pembuatan diagramatau gambar mengenai sesuatu hal, disini data yang disajikan dalam bentuk yang lebih mudah dipahami atau dibaca. Statistika deskriptif merupakan metode-metode yang berkait dengan pengumpulan dan penyajian sekumpulan data, sehingga dapat memberikan informasi yang berguna. Perlu kiranya dimengerti bahwa statistika deskriptif memberikan informasi hanya mengenai data yang dipunyai dan sama sekali tidak menarik kesimpulan yang lebih banyak dan lebih jauh 
dari data yang ada. Kegiatan memeriksa sifat-sifat penting dari data yang ada itu disebut analisis data secara pemerian (deskripsi).

\section{Analisis Inferensia}

Statistik inferensial merupakan kebalikan dari statistika deskriptip, statistika infrensial merupakan statistik yang berkenaan dengan cara penarikan kesimpulan berdasarkan data yang diperoleh dari sampel untuk menggambarkan karakterisktik atau ciri dari suatu populasi. Dengan demikian dalam statistik inferensial dilakukan suatu generalisasi (perampatan atau memperumum) dan hal yang bersifat khusus (kecil) ke hal yang lebih luas (umum). Oleh karena itu, statistik inferensial disebut juga statistik induktif atau statistik penarikan kesimpulan. Pada statistik inferensial biasanya dilakukan pengujian hipotesis dan pendugaan mengenai karakteristik (ciri) dari suatu populasi, seperti mean dan Uji t (Sugiyono, 2006). Statistika inferensi, yang berupa kajian tentang penarikan kesimpulan mengenai keseluruhan objek yang menjadi perhatian namun hanya atas dasar data sebagian objek inilah yang disebut Statistika Inferensial atau Statistika Induktif.

\section{Measurement Model}

Untuk melihat convergent validity dari measurement model dengan indikator refleksif, kita memeriksa korelasi antara score item/indikator dengan skor konstruknya. Indikator individu dianggap reliable jika memiliki nilai korelasi diatas 0.7. Namun pada sumber lain disebutkan bahwa nilai loading diatas 0.3 masih bisa dikatakan reliable.

Tabel 4.1 resılts tor nuter loadings

Output Korelasi Antara Indikator Dengan Konstruk

[ z zsvi-version ]

\begin{tabular}{|c|c|c|c|c|}
\hline & $\begin{array}{c}\text { oriqinal sample } \\
\text { estimate }\end{array}$ & $\begin{array}{c}\text { mean of } \\
\text { subsamples }\end{array}$ & $\begin{array}{l}\text { Standord } \\
\text { deviation }\end{array}$ & $T$-statistic \\
\hline \multicolumn{5}{|l|}{ Ivo } \\
\hline ILW_01 & 0.456 & 0.444 & 0.035 & 5.355 \\
\hline$n w_{-} n ?$ & ก. 58 ก & ก.524 & $0.0 \Omega 8$ & 6. 60.3 \\
\hline ILW_oJ & 0.579 & 0.576 & $0.07 C$ & 7.631 \\
\hline \multicolumn{5}{|l|}{ Iv 1} \\
\hline KKES_UI & U.Sb1 & 0.bot & 0,095 & bis8i \\
\hline KKFS_n? & ก. 576 & 0.559 & 0.07 & 5.825 \\
\hline KKCS_03 & 0.610 & 0.535 & 0.222 & 5.000 \\
\hline \multicolumn{5}{|l|}{$1 \times 2$} \\
\hline K_UI & U.S/6 & ט.b11 & 0.091 & $6.00 /$ \\
\hline K_a? & 0.511 & $n .5>1$ & 0.077 & 5.264 \\
\hline K_O3 & 0.600 & 0.655 & 0.057 & 9.001 \\
\hline K D4 & 0.525 & 0.518 & 0.036 & 6,121 \\
\hline \multicolumn{5}{|l|}{ Ivis } \\
\hline LW_O1 & 0.646 & 0.641 & $0.05 \varepsilon$ & 9.500 \\
\hline $\mathrm{LW}_{-} 02$ & 0.044 & 0.047 & 0,101 & 0.303 \\
\hline LW 03 & 0.609 & 0.654 & 0.034 & 7.245 \\
\hline \multicolumn{5}{|l|}{ lwa } \\
\hline PWOM_01 & 0.490 & 0.495 & 0.035 & 5.794 \\
\hline PwnM_n & 0.713 & 0.577 & 0.147 & 5.0 ก \\
\hline
\end{tabular}


Berdasarkan nilai outer loading diatas dapat dilihat bahwa nilai semua variabel memiliki nilai loading dengan t-statistik > 1.96. Hal tersebut mengindikasikan bahwa variabel - variabel yang digunakan adalah valid. Diskriminan validity indikator refleksif dapat dilihat pada cross loading antara indikator dengan konstruknya.

Tabel 4.2

Hasil Cross Loading Antara Indikator Dengan Konstruk

\begin{tabular}{|c|c|c|c|c|}
\hline & two & WI & $1 \mathbf{2}$ & w3 \\
\hline ILW_01 & J.1.0c & 0.112 & 0.120 & u.tuy \\
\hline rLW oz & 0.580 & $0.6-4$ & 0.558 & 0.580 \\
\hline 11 w_os & $1.5 / 4$ & 11.-4) & I.n.t: & D.tin \\
\hline K 01 & 0.667 & 0.638 & 0.546 & 0.500 \\
\hline x_w? & 1. inthe & Uมन: & a.sit & $0 \ldots-x=$ \\
\hline k_os & 0.702 & 0.010 & 0.000 & $0 .=54$ \\
\hline x_on & 1.the & $n-\infty$ & 1.sen & $n-4 n$ \\
\hline kiars_01 & 0.694 & 0.251 & $0.50=$ & 0.229 \\
\hline KKFS A? & 0.674 & n_f $=75$ & 0.554 & 0.618 \\
\hline KKrs_o3 & 0.700 & 0.010 & 0.710 & 0.000 \\
\hline I w nt & $0.72 n$ & $0.70 ?$ & $0.67 r$ & $0.6-4 \pi$ \\
\hline $\mathrm{Lw}_{-} \mathrm{U}_{2}$ & 0.900 & $0.1 / 9$ & $0.0 / 0$ & 0.011 \\
\hline I w n3 & $7.75 z$ & O.fRI & $7.51:=$ & $0 . \in \cap n$ \\
\hline PWUM_uI & J.52: & U.sisy & 0.30 & $0.10 \mathrm{~J}$ \\
\hline RWOM O2 & 0.407 & 0.311 & 0.247 & 0.150 \\
\hline
\end{tabular}

Dari tabel tersebut dapat dianalisa bahwa korelasi konstruk inovasi layanan terhadap indikatornya (ILW terhadap lv0) lebih tinggi dibandingkan korelasi konstruk inovasi layanan dengan konstruk lainnya. Hal ini menunjukkan bahwa konstruk inovasi layanan memprediksi indikator pada bloknya lebih baik dibandingkan dengan indikator di blok lainnya. Korelasi konstruk kepercayaan terhadap indikatornya ( $\mathrm{K}$ terhadap lv1) lebih tinggi dibandingkan korelasi konstruk kepercayaan dengan konstruk lainnya. Hal ini menunjukkan bahwa konstruk kepercayaan memprediksi indikator pada bloknya lebih baik dibandingkan dengan indikator di blok lainnya.

Tabel 4.3

\section{Diskriminan Validity}

\section{Correlations of the latent variables}

[ Liv varsien]

\begin{tabular}{|c|c|c|c|c|}
\hline & Iv0 & IvI & Iv2 & Ivs \\
\hline Iv0 & 1.005 & & & \\
\hline Iv1 & 0.734 & 1.000 & & \\
\hline Iv3 & 0.707 & 0.724 & 1.070 & \\
\hline Iv3 & 0.721 & 0.716 & 0.120 & 2.0 .30 \\
\hline Iv4 & 0.195 & 0.701 & 0.331 & 0.331 \\
\hline
\end{tabular}

\begin{tabular}{|l|l|}
\hline & Iv4 \\
\hline Ivo & \\
\hline Iv1 & \\
\hline Iv? & \\
\hline Iv3 & \\
\hline Iv1 & I.00J \\
\hline
\end{tabular}


Dari tabel diatas dapat disimpulkan bahwa akar AVE konstruk loyalitas website (lv 3) lebih tinggi dibandingkan korelasi loyalitas website tehadap inovasi layanan. Begitu juga terjadi pada konstruk kualitas pelayanan online, loyalitas terhadap website, persepsi internet keahlian dan perilaku word of mouth terhadap inovasi layanan. Jadi, semua konstruk dalam model yang diestimasi memenuhi kriteria dikriminan validity.

Tabel 4.4

\section{Composite Reliability}

L CSV-Version I

\begin{tabular}{|c|c|}
\hline & $\begin{array}{l}\text { Composite } \\
\text { Roliability }\end{array}$ \\
\hline INo & 0.551 \\
\hline IvI & 0.602 \\
\hline $\ln 2$ & 0.631 \\
\hline WB & 0.746 \\
\hline In: & 0.536 \\
\hline
\end{tabular}

Dari tabel tersebut dapat dianalisis bahwa composite reliability cukup memuaskan yakni disekitar angka 0.6.

Tabel 4.5

Nilai R-Square

\section{[ csv-version ]}

\begin{tabular}{|c|c|}
\hline & R-square \\
\hline INO & \\
\hline Iv1 & 0.539 \\
\hline Iv2 & 0.497 \\
\hline Iv3 & 0.514 \\
\hline Iv4 & 0.245 \\
\hline
\end{tabular}

Dari tabel tersebut dapat dilihat bahwa nilai r square cukup besar di masing - masing variabel. Dapat dikatakan bahwa pengaruh variabel kepercayaan, kualitas pelayanan online, loyalitas terhadap website, persepsi internet keahlian dan perilaku word of mouth terhadap inovasi layanan cukup besar.

Tabel 4.6

\section{Koefisien Jalur Struktural}

\section{results for inner weights}

[c-v-versinn ]

\begin{tabular}{|c|c|c|c|c|}
\hline & $\begin{array}{l}\text { ariginal somple } \\
\text { estimate }\end{array}$ & $\begin{array}{c}\text { mean of } \\
\text { subsamples }\end{array}$ & $\begin{array}{l}\text { Standard } \\
\text { deviation }\end{array}$ & I-Statistic \\
\hline IVD->IVI & 0.734 & $0.74 \varepsilon$ & 0.073 & 10.033 \\
\hline $\operatorname{lv}[\rightarrow \mid \mathrm{l})$ & 7.705 & 0.716 & ก.054 & 10.9 .30 \\
\hline $\operatorname{lv} 0->\operatorname{lv} 3$ & $0.7: 2$ & $0.72 z$ & 0.077 & 9.311 \\
\hline IvD $\rightarrow$ Iv 4 & 0.492 & 0.511 & 0.112 & $4,4: 4$ \\
\hline
\end{tabular}




\section{Hasil Koefisien Jalur Struktural Dan Indikator Serta Nilai Sigfnifikansi}

\begin{tabular}{|c|c|c|c|c|}
\hline & 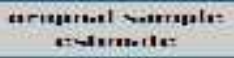 & 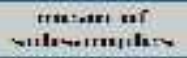 & 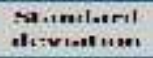 & T-statistic \\
\hline \multicolumn{5}{|l|}{$\operatorname{IVD}$} \\
\hline LW U1 & $0.4=0$ & 0.424 & 0.485 & 3.830 \\
\hline$n w$ n_ns & n.tro & a. $7 n$ A & c.enn & n.ting \\
\hline nw_03 & 0.570 & 0.578 & $c . c 76$ & 7.681 \\
\hline \multicolumn{5}{|l|}{ 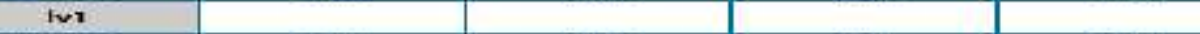 } \\
\hline KKES_O1 & $0.5 \leq 1$ & 0.553 & 0.000 & 5.581 \\
\hline kres :- as & 13:LC, & $7-x, 4$ & E.t.44 & fw.ll: \\
\hline KKES_03 & 0.610 & 0.585 & 0.122 & 5.003 \\
\hline \multicolumn{5}{|l|}{ tos } \\
\hline K_oI & 0.346 & 0.341 & 0.091 & 0.007 \\
\hline $\boldsymbol{\alpha} \mathbf{w 2}_{2}$ & 11.511 & $1,72=$ & noter & Sient \\
\hline$\kappa_{\text {__oJ }}$ & 0.600 & 2.509 & 0.067 & 9.001 \\
\hline K n4 & 11.sins & $11.51 x$ & E.tinn & $n .1 \% 1$ \\
\hline \multicolumn{5}{|l|}{ Iva } \\
\hline $2010 x$ & 0.646 & $0.34=$ & 0.608 & $y>0$, \\
\hline $1 w_{-} n z$ & n.nAt & $7-7+7$ & 0.101 & ก.ากา \\
\hline $2 x_{-} 03$ & 0.600 & 0.504 & C.C84 & 7.245 \\
\hline \multicolumn{5}{|l|}{ Iva } \\
\hline PWOM_O1 & 0.450 & 0.495 & 0.085 & 5.704 \\
\hline procim os & $11.9 x$ & $\operatorname{an} i y$ & 1/.11:? & S.tuln \\
\hline
\end{tabular}

Hasil estimasi menunjukkan bahwa semua loading factor pada result for outer loadings adalah signifikan $(<0.05)$. Pengaruh variabel kepercayaan, kualitas pelayanan online, loyalitas terhadap website, dan perilaku word of mouth terhadap inovasi layanan ditunjukkan dengan nilai t-value yang signifikan diatas 1.96. Hal ini menunjukkan bahwa adanya pengaruh positif dan signifikan antara variabel kepercayaan, kualitas pelayanan online, loyalitas terhadap website dan perilaku word of mouth terhadap inovasi layanan.

Tabel 4.8

Hasil Pengujian Hipotesis

\section{Standardized}

\section{Hypotheses}

\section{Coefficient Beta}

( $\beta)$

\section{H1 :}

Pengaruh positif inovasi

$0,734 \quad 10,033$

$T$ - Statistic

Keputusan

terhadap service quality

H2 :

pengaruh positif inovasi

0,705

10,939

Ho ditolak, Ha

terhadap kepercayaan

\section{H3 :}

pengaruh positif inovasi

terhadap loyalitas

\section{0,717}

9,314

Ho ditolak, Ha diterima

\section{H4 :}

pengaruh positif inovasi

Ho ditolak, Ha diterima

terhadap word of mouth 


\section{Pengujian Hipotesis 1 :}

Hipotesis satu menguji pengaruh hubungan positif antara inovasi dengan service quality. Hipotesis nol (Ho) dan hipotesis alternatifnya (Ha) secara berurutan diajukan sebagai berikut :

Ho 1: Tidak terdapat pengaruh positif inovasi dengan service quality.

Ha 1: Terdapat pengaruh positif inovasi dengan service quality.

Berdasarkan hasil pengujian hipotesis yang dilakukan, maka menunjukkan bahwa inovasi secara positif berhubungan dengan e service quality dapat di dukung. Oleh karena t-value yang dihasilkan 10,033 dan nilai tersebut lebih besar dari signifikansi (>1.96) maka H1 didukung yang berarti terdapat pengaruh positif inovasi dengan service quality.Hasil hipotesis tersebut juga di dukung dengan beberapa teori yang menyatakan betapa pentingnya peranan inovasi di dalam suatu perusahaan, berikut teori-tori pendukung dari beberapa sumber. Perusahaan yang selalu berinovasi dan berkreasi dengan hal-hal yang baru yang difundalisasi oleh system research dan development yang sangat super itulah yang sanggup bertahan dalam kondisi apapun dan jaminan keberlangsungan dimasa depan.

\section{Pengujian Hipotesis 2 :}

Hipotesis satu menguji pengaruh positif inovasi dengan kepercayaan. Hipotesis nol (Ho) dan hipotesis alternatifnya (Ha) secara berurutan diajukan sebagai berikut

Ho 2: Tidak terdapat pengaruh positif inovasi dengan kepercayaan.

Ha 2: Terdapat pengaruh positif inovasi dengan kepercayaan.

\section{Pengujian Hipotesis 3 :}

Hipotesis satu menguji pengaruh hubungan positif antara inovasi dengan loyalitas. Hipotesis nol (Ho) dan hipotesis alternatifnya (Ha) secara berurutan diajukan sebagai berikut

Ho 3: Tidak terdapat pengaruh positif inovasi dengan loyalitas.

Ha 3: Terdapat pengaruh positif inovasi dengan loyalitas.

Berdasarkan hasil pengujian hipotesis yang dilakukan, maka menunjukan bahwa terdapat pengaruh positif inovasi terhadap word of mouth, oleh karena t-value yang dihasilkan 4,434 dan nilai tersebut lebih besar dari signifikansi (>1.96) maka H1 didukung yang berarti terdapat pengaruh positif inovasi terhadap word of mouth. Dengan di dukung beberapa pendapat dari beberapa ahli mengenai teori tentang perilaku mulut ke mulut atau word of mouth.

Promosi merupakan salah satu faktor penentu keberhasilan suatu program pemasaran. Betapapun berkualitasnya suatu produk ataupun jasa, bila konsumen belum pernah mendengarnya dan tidak yakin bahwa produk tersebut dapat berguna, maka konsumen tidak akan pernah membeli produk tersebut. Salah satu alat promosi yang paling ampuh adalah dengan system WOM.Harrison-Walker dalam Brown et al.(2005) menyatakan bahwa WOM merupakan sebuah komunikasi informal diantara seorang pembicara yang tidak komersil dengan orang yang menerima informasi mengenai sebuah merek, 20 produk, perusahaan atau jasa. 


\section{Pengujian Hipotesis 4 :}

Hipotesis satu menguji pengaruh hubungan positif antara inovasi dengan word of mouth. Hipotesis nol (Ho) dan hipotesis alternatifnya (Ha) secara berurutan diajukan sebagai berikut :

Ho 4: Tidak terdapat pengaruh positif inovasi dengan word of mouth.

Ha 4: Terdapat pengaruh positif inovasi dengan word of mouth.

\section{KESIMPULAN}

Inovasi secara positif berpengaruh terhadap e service quality dapat di dukung. Oleh karena t-value yang dihasilkan 10,033 dan nilai tersebut lebih besar dari signifikansi (>1.96) maka H1 didukung yang berarti terdapat pengaruh positif inovasi terhadap service quality. Menurut Han et al. (2008) mengemukakan bahwa inovasi tidak hanya terpaku pada masalah teknis namun juga terkait dengan aspek administrasi organisasi. Munculnya inovasi produk pada dasarnya adalah untuk memenuhi permintaan pasar, sehingga inovasi produk merupakan salah satu yang dapat digunakan sebagai keunggulan kompetitif bagi perusahaan. Berdasarkan hasil pengujian hipotesis yang dilakukan, maka menunjukan bahwa Inovasi secara positif berpengaruh terhadap kepercayaan, oleh karena t-value yang dihasilkan 10,393 dan nilai tersebut lebih besar dari signifikansi (>1.96) maka H1 didukung yang berarti terdapat pengaruh positif inovasi terhadap kepercayaan. Kepercayaan merupakan pondasi dari bisnis, suatu transaksi bisnis antara dua pihak atau lebih akan terjadi apabila masing-masing saling mempercayai. Kepercayaan ini tidak begitu saja dapat diakui oleh pihak lain/mitra bisnis, melainkan harus dibangun mulai dari awal dan dapat dibuktikan (Rofiq 2007).

Berdasarkan hasil pengujian hipotesis yang dilakukan, maka menunjukan bahwa terdapat pengaruh positif inovasi terhadap word of mouth, oleh karena t-value yang dihasilkan 4,434 dan nilai tersebut lebih besar dari signifikansi (>1.96) maka H1 didukung yang berarti terdapat pengaruh positif terhadap inovasi dengan word of mouth. Dengan di dukung beberapa pendapat dari beberapa ahli mengenai teori tentang perilaku mulut ke mulut atau word of mouth. Seperti yang dinyatakan Davidow (2003): "that word of mouth is actually a U shaped relationship, where satisfied complainers spread positive word of mouth valance, and dissatisfied complainers spread negative word of mouth valance" Bahwa sebenarnya hubungan dari mulut ke mulut berbentuk U, di mana apabila seseorang puas maka ia akan menyebarkan berita positif dari mulut ke mulut, tapi apabila mengeluh tidak puas maka ia akan menyebarkan berita negatif dari mulut ke mulut. Pengalaman yang kurang memuaskan pada customer dapat memunculkan berbagai respon kepada perusahaan.

\section{DAFTAR PUSTAKA}

[1] Aaker, D.A., 2007. Innovation: brand it or lose it. California Management Review 50 (1), 8-24 Anderson, J.C., Narus, A., 2000. A model of distributor firm and manufacturer firm working partnerships. Journal of Marketing 54, 42-58, January.

[2] Anselmsson, J., Johansson, U., 2009. Retailer brands and the impact on innovativeness in the grocery market. Journal of Marketing Management 25 (1-2), 75-95

[3] Afriansyah Dedi, Nugrahani Rah Utami,2012. Pengaruh Word Of Mouth Marketing Terhadap Keputusan Pembelian Konsumen (Suvey Pada Konsumen Resto D'Cost Seafood Sukajadi Bandung. Tugas Akhir University Telkom.

[4] Bridges, E., Florsheim, R., 2008. Hedonic and utilitarian shopping goals: the online experience. Journal of Business Research 61 (4), 309-314. 
[5] Brodie, R.J., Whittome, J., Bush, G., 2008. Investigating the service brand: a customer value perspective. Journal of Business Research. doi:10.1016/ j.jbusres.2008.06.008.

[6] Carlson, J., O'Cass, A., 2010. Exploring the relationships between e-service quality, satisfaction, attitudes and behaviours in content-driven e-service web sites. Journal of Services Marketing 24, 112-127.

[7] Chen, J., Dibbs, S., 2010. Consumer trust in the online retail context: exploring the antecedents and consequences. Psychology \& Marketing 27 (4), 323-346.

[8] Cho, Y., Menor, L., 2010. Toward a provider-based view on the design and delivery of quality e-service encounters. Journal of Service Research 13 (1), 83-95.

[9] Davis, A., Khazanchi, D., 2008. An empirical study of online word-of-mouth as a predictor for multi-product category e-commerce sales. Electronic Markets 18 (2), 130141.

[10] Ha, S., Stoel, L., 2009. Consumer e-shopping acceptance. Antecedents in a technology acceptance model. Journal of Business Research 62, 565-571.

[11] Hausman, A., Siekpe, J., 2009. The effect of web interface features on consumer online purchase intentions. Journal of Business Research 62 (1), 5-13.

[12] Hoffman, D., Novak, T., 2009. Flow online: lessons learned and future prospects. Journal of Interactive Marketing 23 (1), 23-34.

[13] Hwang, Y., Kim, D., 2007. Customer self-service systems: The effects of perceived web quality with service contents on enjoyment, anxiety, and e-trust. Decision Support Systems 43, 746.

[14] M. (Ed.), Review of Marketing. American Marketing Association, Chicago, pp. 236292.

[15] Kleijnen, M., de Ruyter, K., Wetzels, M., 2007. An assessment of value creation in mobile service delivery and the moderating role of time consciousness. Journal of Retailing 83 (1), 33-46.

[16] Lee, J., Park, H., Han, H., 2011. The different effects of online consumer reviews on consumers' purchase intentions depending on trust in online shopping malls: an advertising perspective. Internet Research 21 (2), 187-206.

[17] Made Caesar Surya Dwi Putra, Ni Wayan Ekawati, 2017. Pengaruh Inovasi Produk, Harga Citra Merek dan Kualitas Pelayanan Terhadap Loyalitas Pelanggan Sepeda Motor Vespa, Vol.6 No.3 1674-1700, E-Jurnal Manajemen Unud, Denpasar-Bali. 